\title{
Geopolitical Research on THAAD’s (Terminal High Altitude Area Defense) Deployment in South Korea
}

\author{
Qi Haotian \\ Major: Politics Minor: Policy Economics \\ New York University College of Art and Science \\ Address: New York, NY 10003
}

Keywords: THAAD, ICBM, DPRK.

\begin{abstract}
This paper focuses on the impact of THAAD's (Terminal High Altitude Area Defense) deployment in South Korea by utilizing geopolitical analysis based on theoretical framework of geographer Saul Bernard Cohen to locate geopolitical features and definitions of Korea Peninsula, combining with major events that were shaping a new post-world-war order; it concludes a proposal that only peaceful and positive sum foreign policy would be the most beneficial for the future of Korean People. This paper begins with establishing a historical background of North Korea nuclear capability and global denuclearization effort related to North Korean's geopolitical definitions and South Korean people's reaction to North Korea over time. Then, from the results of geopolitical analysis, it demonstrates that war is an irrational option, which will break the ameliorating geopolitical equilibrium and bring more destruction to the world.
\end{abstract}

\section{Introduction}

In the last ten years, Korean Peninsula, mainly north, has once again become a focal point of international politics and geopolitics for its progress on nuclear weapons and unique political regime. With North Korea's military might and developing capability of intercontinental ballistic missiles (ICBM), North Korea has broken the military power-equilibrium in the region. Most of the U.S. military bases in the Pacific Ocean area are now potential targets for North Korea, and even the U.S. west coast has become a reachable target if the claimed range of North Korean ICBMs is true. South Korea, however, despite its lead in technology and economy, chooses not to nuclearize and continue to fight for a denuclearized Korea, which is also a primary agenda for the newly elected South Korean president, Moon Jae-in. Basing on history and geopolitical analysis, this essay aims to examine the effects and consequences of THAAD's (Terminal High Altitude Area Defense) deployment in South Korea with data. THAAD was a crucial part of "Rebalance to Asia" policy by the Obama administration. However, THAAD is also a consequential action of international relations, geopolitics, and historical factors. Initially, THAAD intensified the antagonism between two Korean Countries, but polls by Korea Gallop Research Institute have shown a trend of growing support for THAAD deployment in 2017. Despite the early oppositions from within and from China and Russia, THAAD did eventually create a new balance for two Koreas militarily and made possible for South Korea to keep on its endeavor towards a denuclearized and peaceful. However, underneath the deployment, undergoes conflicting geopolitical interests from other nations. Therefore, this essay would first discuss the regional geopolitical conditions before THAAD deployment and then move to its impacts. Finally, with every point made, peace itself should be obviously the optimal option for all sides.

\section{Background Information}

Interactions of major powers in Korean Peninsula starts from world wars. Underlying these wars and attempts to control Korea, were post-world-war bipolar geopolitical interests. Geopolitics is, as 
CongDe Liu described, "to analyze the geographical features and pattern's relationship to human affairs on a global perspective; from the analysis and from examining history, to find patterns in geographical characteristics that may contribute to national decision-making” [7]. Thus, recognizing and utilizing geopolitics is the most efficient way to present North Korea's stance in global geopolitical equilibrium, which wouldn't be possible without American geographer, Saul B. Cohen. Therefore, to understand North Korea with Cohen's theories, we would have to look first inward the country then outward.

Location. On the side of North Korea, its location between South Korea, China, Japan, United State, and Russia has destined North Korea to be another center where geopolitical interests from powers converge. As shown in Korea's history, the Democratic People's Republic of Korea (abbreviated DPRK), is, as described by Saul Bernard Cohen in his "Geopolitics," the "last of the Stalinist states" [2]. DPRK Shares boarder with China in the north and South Korea in the south, and further north, Russia. West of DPRK is the Yellow Sea, and east of DPRK is the Sea of Japan and Japan. Inside the border, Geographer Cohen had the most accurate description on poor farming conditions in the North- "the Achilles' heel of the North is agriculture. Little farmland was available because of the rocky and mountainous terrain, poor soil, and a short growing season. The peninsula in its entity is only 20 percent arable land because of the terrain, but there is even less land portionally available in the North..." [2] Lack of farmlands and cold weather, plus the endless wars, lead to famines and millions of deaths thus followed.

War. Korea, namely Greater Korean Empire as it was proclaimed, was once a hermit kingdom in Ming China's geopolitical sphere until it was annexed by Imperial Japan in 1910. Annexation lasted till the surrender of Japan. Soviet Union, and the United States then took control and divided Korea into two-the socialist Democratic People's Republic of Korea, and the capitalist Republic of Korea. Later, Korean War Erupted as a DPRK's attempt to oust US influence in Korean Peninsula. At the beginning of the Korean war, DPRK defeated South Korean within two months. In September of 1950, a United Nations' counter offense force quickly strokes back, pushing the North Koreans close to its borderline with China. Concerning geopolitical security, in October, China dispatched more than 1 million "volunteer" soldier into Korean War alone with the help of the North Korean army and Soviet air force. A fast concentration of troops from all sides quickly lead to massive casualties, but after three years of back and forth, the war did end at the 38th parallel, which eventually becomes the demilitarized zone separating North and South Korea Until today.

\section{Geopolitical Analysis}

“Four Pillars of Power". Base on geographical conditions, derives, according to Cohen, “four pillars of power-Military strength and willingness to use it, surplus economic energy, Ideological leadership, cohesive governance" [1] . Among them, North Korea has the largest military relative to its population. Though DPRK's military equipment are relatively outdated compare to its south counterpart and the U.S., the sheer number of functioning artillery is still large enough to destroy south Korea if war does erupt. Extremely concentrated control over military is number one priority for Kim regime because military is the cornerstone of DPRK's existence. Each year, more than twenty percent of DPRK's GDP counts towards military budget, and it greatly undermined the annul DPRK economic output. In term of Ideological leadership, DPRK has a strictly managed socialist ideology that ensures loyalty to the supreme leaders and to the DPRK. Any disruptive or corrupt figures in the government will be punished with death or exile. Party members and government official has to be absolutely loyal to Kim family. Any trace of otherwise would lead to disastrous consequence to the official as treason is regard as a shameful and deadly crime. In 2013, according to Korea JoongAng Daily, an execution of 10 DPRK government officials was arranged to be witnessed by 10000 people while the prisoners were killed with machine guns and their relatives imprisoned. [3] Fear and vast amount of propaganda combined, have ensured an ordered government for Kim. Economy is now the most emergent issue, thus the special economic zones(SEZs) in North Korea are now the main channels of growth (plus smuggling with neighboring countries). Meanwhile, these 
SEZs are also the points where the U.S. applies most pressure with international sanctions.

"Patterns". From prior internal factor, develops the patterns of Geopolitical equilibrium. Geopolitical structure wise, Cohen defined Patterns as "the shape, size, and physical/human geographical characteristics of the geopolitical unit and the networks that tie them together, and these distinguish geopolitical units from other units" [2]. And "Features are the political-geographical nodes, areas, and boundaries that contribute to the unit's uniqueness and influence its cohesiveness and other measures of its structural effectiveness" [2].

"Geostrategic Realms". Foremost of the features and patterns are geostrategic realms which can be understood as "These realms are parts of the world large enough to possess characteristics and function that are globally influencing and that serve the strategic needs of the major powers, states, and regions they comprise” [2]. In Cohen's terms, DPRK locates at the boundary of East Asia Realm and Asia Pacific realm and very close to Eurasian continental realm [2].

“Geopolitical Regions”. Stem from geopolitical realms is “Geopolitical regions”- “The second level of geopolitical structure is geopolitical regions [2]. Most of the regions are subdivisions of realms, although some may be caught between or independent of them [2]. Regions are connected by geographical contiguity and political, culture, and military interactions and in many cases by historical migration and intermixture of people share histories of national emergence” [2]. Around DPRK are two borderlines that lead to Asia Pacific Rim to the East and Russia to the north, plus the East Asia Rim which North Korea resides in. Knowing the DPRK's Unique location between geopolitical powers and geopolitical structure, it is clear that when all the borderlines and connections to realms centralize together, North Korea could either be a link to every nation around it or a battlefield of conflicting interests.

“Gateway or Shatterbelt”. In Cohens terms, DPRK can easily become either a "Gateway” which stands for "the flow of ideas, migrants, trades, capital, communications, and arms takes place beyond, as well as within, the different structural levels of realms, regions, and state" and promotes globalization or "Shatterbelts" which is "strategically oriented regions that are both deeply divided internally and caught up in the competition between great powers of the geostrategic realms" or both [2]. "Shattlerbelt", as suggested by Cohen, "presents an equal playing field to two or more competing for global powers operating from different geostrategic realms" [2]. It used to be the Soviet Union, but nowadays it has transformed into a "crash zone" between China, Russia, US, and Japan [2]. As a nation, to subsist under such conditions requires them to first break out from all destabilizing elements and to fortify its own control of the region. Relying on other powers can only be temporary for if war breaks out, Korea would only be destroyed again. Consequently, DRPK has to stand on its own, thwarting and minimizing all external threats for only when stabilized, Korea would then be able to thrive as a "gateway" instead of a "crash zone". Nuclear weapons and more-substantial-than-usual military presence are thus necessary for DPRK.

Survive and Unite. DPRK needs to survive and stabilize, but it also has to face the fact that North Korea is a relatively small nation compared to its neighbors. Following the "order of political power of states" laid out by Cohen, North Korea is on the third tier for it replies heavies on first tier powers around it, and it also does not have the power to shift global geopolitical order just by itself [2]. Even DPRK has a determined intention to gain control over itself and keep out all external destabilizers to rise up and become the second-tier power. It would still have to rely heavily on countries around it with strict control for if one side has too much stake in DRPK, harming the status quo and equilibrium, the conflict will rise again. On the other hand, if North Korea were not forced to be a "playing field" for world powers, it is very likely that it would have to rely on itself and to subjectively reject all influence from outside the country. Even "gateway" would bring much prosperity to DPRK and South Korea, and even North and South have the intention to unite and become a complete gateway linking realms, it still would not be possible for the geopolitical conflicts between first tier powers have not been settled. Also, as a result of North Korea's seclusion, its urbanization is slow for subsequently low economic output and insufficient industrialization. Under state-run and planned economy, economic activity is progress at very slow pace compared to its southern counterpart's capitalistic regime. In addition, despite the heritage of being one nation a century ago and a consensus 
that being a "gateway" as one body would be beneficial for both North and South Korea. Two Koreas are unable to proceed on their unity for ideological and political differences and convergence of modern-day geopolitical interests. However, according to Fu Ying's report on North Korea Nuclear Issue, North Korea has assumed the role of mediator rather than intervener, as it has become active in promoting negotiations over the unification of the two Koreas [4]. The new reality is that the two geostrategic realms that now clash in a growingly controlled environment. North Korea was forced to use all resources onto maintaining the regime and the DPRK, then to seek opportunities to expand DPRK's self-interests. War is the worst scenario for all sides, but the geopolitical structure and analysis has shown that North Korea, as a state, have to survive, which is also the primary driver for its endless endeavor to build nuclear capabilities. In the circumstance of DPRK, nothing would be more vital than self-defense and abilities to stand firmly between geopolitical superpowers. Only then, establishing from the assured safety as a state and as a regime, the unity and economic power of DPRK's economy could grow.

Peace. Pease can offer DPRK with more time to build massively destructive weapons for defense and rely less on manpower, so it can advert human capital onto the economic progress within the nation. "When Korea emerged from World War II, it was the North that had the bulk of the peninsula's industry and its mineral resources (coal, iron, copper, lead, uranium, manganese)” [2]. Constant famine has led North Koreans to defect to South Korea or immigrant into China illegally. Interestingly, a study by KongDan Oh from the Foreign Policy Research Institute have has shown a dramatic decrease in defector in recent year, though North Korean's GDP per capita is still very low, Kim did manage to sustain DPRK on itself even under heavy sanctions by international institutions [8]. Also, another expert in this field, Rensselaer Lee, suggested in his report that "Beijing does not feel directly threatened by North Korean's nuclear program. China is more worried about North Korean Weakness than Strength, fearing a large migrant influx into northeast China in the event of a collapse of the Kim regime in Pyongyang" [5]. Kim Jong-un's only constraints are the fear that the Chinese might someday pull the plug on his economy, and the fear that his hard-line military might turn against him [8].

The U.S. and Nesslerization of DPRK The U.S. has a very clear stance on North Korea, which is to ensure a denuclearized DPRK and peaceful solution to Kim regime. But the stance was not strong enough to force DPRK to give up. "Earliest North Korean's effort to Nuclear capabilities can be found in its "all-fortressization" policy back to 1960s" [4]. With ongoing threats from South Korea and the US, DPRK went to the Soviet Union seeking help building nuclear weapons, though it was rejected, Soviet Union did agree to build a nuclear power plant and train a team of Nuclear power specialists complementarily for DPRK. "In 1965 a Soviet IRT-2M research reactor was assembled for this center. From 1965 through 1973 fuel (fuel elements) enriched to 10 percent was supplied to the DPRK for this reactor" [4]. After DPRK has obtained the ability to produce and preserve Uranium, it immediately shifted their focus onto refining Uranium to weapon grade. In 1980s, North Korean nuclear weapons programs start with the construction of new generation of 200 MWe nuclear power plant and Uranium refinement capabilities [4]. Also in the 1980s, DPRK refused to sign the Nuclear Non-Proliferation Treaty, and the United States started to be alarmed by DPRK's potential ability to construct nuclear weapons [4]. With rounds of maneuvering, in 2013, North Korea conducted its first nuclear test, and in 2017, DPRK has officially become a fully developed nuclear power, with ample uranium in stock, augmenting its nuclear power while threatening the U.S. with preemptive nuclear strike on Guam islands and North Pacific Ocean, destroying marine life and potentially causing the biggest tsunami in known history on almost all coastline in the world. From the pass interactions, we see a frustrating process of prolonged negotiations and failed attempts at carrying out agreements. Overly protracted communication and shifting agendas from president to president has eventually led to Nuclearized North Korea. Fortunately, U.S. has the technology to block suicidal nuclear strikes from North Korea. Therefore, aside from the negotiations, THAAD did proactively prohibit any potential nuclear strikes by North Korea and even China and Russia in the region, which is very successful and effective for the U.S. Until now, THAAD is continuing to provide a hard safeguard for any DPRK's unilateral actions, but it would never be able to stop DPRK from deepening its 
nuclear-weaponry technology.

Denuclearization. After the war, to reach and understand my proposal, understanding three stages of DPRK's denuclearization is critical. The first stage is U.S.'s unilateral negotiations with DPRK after 1953 armistice has been signed, and USSR provided DPRK with a Nuclear reactor for energy demands with. The reactor was built, but fuel supply was controlled by USSR. DPRK was a Nuclear Non-proliferation treaty member, but its Nuclear technology has been developing in DPRK nonstop until the DPRK Nuclear research team were able to fabricate their fuel and started to construct new nuclear plants. U.S. was alerted and started its negotiations with DPRK to forfeit their nuclear capabilities in exchange for a new generation of U.S. DPRK cautiously accepted the offer which was successful at first but an utter failure in implementation for both sides was not willing to make the first step, and the nuclear research accelerates in the meantime.

The Second Stage. The second stage is marked by DPRK's Byungjin policy, which to reform and grow its economy and build nuclear weapons [5]. U.S. was determined to dismantle all DPRK's Nuclear capabilities, and they did again come into agreement with help from China. "The negotiation starts with three parties, but soon turn into six parties" [4]. Here, Ying Fu's account on these particular period of U.S. DPRK interaction is most revealing. She described several occasions where DPRK was at least acting like they were willing to cave in as follows. The fourth round of Six-Party Talks. "North Korea, for the first time, promised to give up all of its nuclear weapons and its current nuclear program, and South Korea, also clearly expressed that it would not develop nuclear weapons" [4]. "North Korea remained firm in sticking to a package settlement of the nuclear issue. It proposed a four-stage resolution, with each stage requiring 'simultaneous action' from the United States” [4]. And "on October 23, U.S. Secretary of State Madeleine Albright started a historic two-day visit to Pyongyang, where she was met by Kim Jong-il himself” [4]. "After secretary Albright returned home, the U.S. planned for a visit by President Clinton to North Korea and a possible return visit by Kim Jung-il” [4]. "Clinton told her that he wished he had taken up the chance to go to North Korea instead of staying in Washington to make a final push toward a peace agreement in Middle east" [4]. "But on September 23, 2005, almost at the same time the Six-Party talks were in progress, the U.S. Treasury Department, without any warning, openly accused the Macao-based Banco Delta Asia(BDA) of money laundering and circulating counterfeit bank notes for several North Korean accounts" [4]. "Then on September 21, U.S. blacklisted eight North Korean enterprises and froze their U.S. asset" [4]. The effort was again forfeited for unassured implementation.

The Third Stage. The third stage is a stage of mistrust and antagonism, starts from Bush addressing DPRK leader as "tyrant," continues with Obama's "strategic patience” strategy, which is no matter how North Korea conducted itself, the U.S. did not give any serious considerations to Pyongyang's security threats. "If North Korea were willing to negotiate, the U.S. would talk but also with no intention to make any progress. If North Korea chooses confrontation, the U.S. will intensify sanctions. The ultimate purpose was to see the North Korean regime collapse under constant pressure" [4]. DPRK has lost their hope to every cooperate with the U.S. Realizing that It could no longer trust the U.S., and, in the face of hostile American policy, it needed to develop nuclear weapons to guarantee its security [5].

“Gadhafi” Then the game changer hits DPRK. In December 2003, Muammar Gadhafi, who was also a dictator in Libya at the time, announced to the world that his government would give up all weapons of mass destruction and accept inspections by United Nations. As negotiated, the U.S. would then repeal its sanctions on Libya and the claims that suggests Libya as a sponsor of terrorism. The U.S. even reopened their diplomatic tie with Libya. But, as Rensselaer quoted from one of the North Korea state broadcast: "eight years later, he(Gadhafi) was overthrown by rebel forces with the assistance of NATO, and later murdered-in a most grisly fashion..." [5]. This bloody murder lead to the third stage, which is still ongoing, "hundreds of economic sanctions have been levied upon DPRK, and yet its people did not rebel, but they have pursued a bottom-up economic evolution and now survive for the most part by their own means, even though these means are mostly illegal” [8].

Survive Under Sanctions. Also in a report by Rensselaer W. Lee, and William Severe from the Foreign Policy Research Institute had a detailed explanation of why sanctions were not as effective as 
preplanned. The North Koreans people have learned how to make their own living, even if most of them it is not a very good living [8]. Plus, the Chinese semi-seriousness about really shut down every connection like shown by John Park and Jim Walsh, to 'rent Chinese countries to carry out procurement of sanctioned products,' which may include western-made technologies and components [5]. "Chinese banks are used to sending and receiving payment along with the procurement-logistics chain-North Koreans are uninvolved in these transactions. Such deals are brokered by Chinese intermediaries, some with established representation aboard" [5]. "According to a February 2017 UN panel of expert's report, a total of 116 member states had failed to submit required reports on what steps they have taken to implement the sanctions regime (investigations, seizures, arrests, and so on) to UN authorities, which likely signifies that they have done nothing or next to nothing” [5].

\section{South Korea}

On the side of South Korea, Gallup Korea, a data company that has been doing surveys on North Korean nuclear issues since 2000. Its reports were majorly focused on social and entertainment issue in the early years. Very few surveys were collected until recent 3 to 4 years. However, within these three years, result from questions about North Korea have shown an intensifying sense of crisis. The first question is "whether you feel threaten by North Korea."

The second is "Do you think South Korea should have its nuclear weapons?"

The third is “do you support or oppose THAAD deployment?" In general, South Koreans believe firmly that North Korea will not give up its Nuclear weapons and China would eventually take more responsibility on North Korea issue.

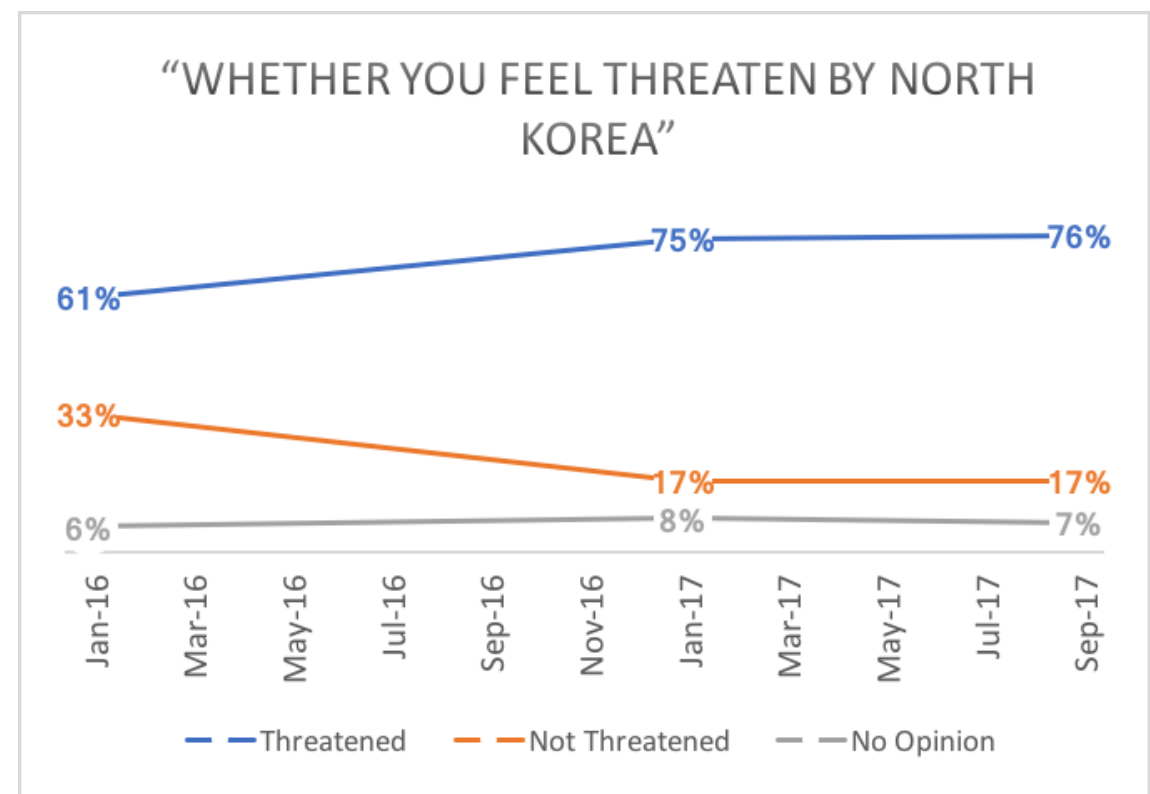

Source: Korea Gallop Research Institute (http://www.gallup.co.kr/gallupdb/report.asp) 


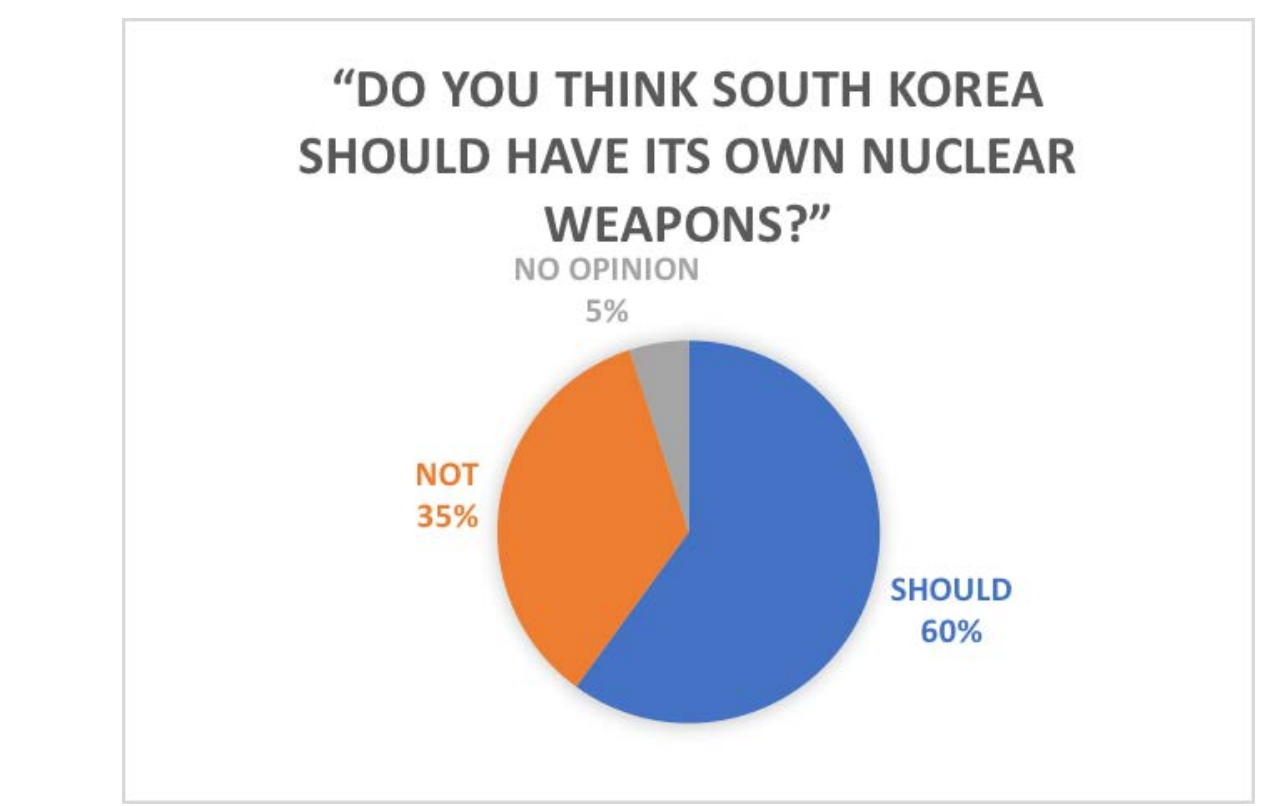

Source: Korea Gallop Research Institute (http://www.gallup.co.kr/gallupdb/report.asp)

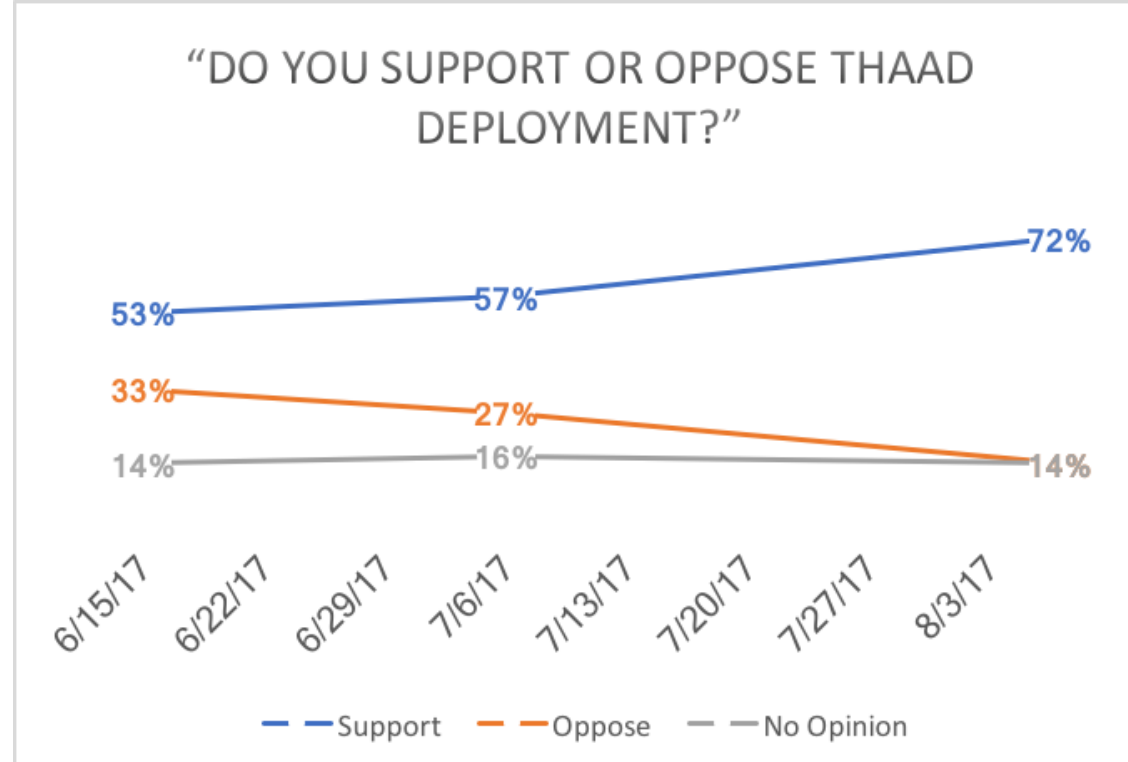

Source: Korea Gallop Research Institute (http://www.gallup.co.kr/gallupdb/report.asp)

For the first question, in January 2016, 61\% South Koreans feel threatened, and 33\% do not. Twelve months later, after North Korea's 5th nuclear test, $75 \%$ feel threatened, and $17 \%$ do not. Then nine months later, in September of 2017, 76\% feel threatened. This number went up drastically after constant nuclear tests and development of hydrogen bomb. The second question, from 54\% South Koreans think South Korea should have its own nuclear weapons in January 2016 to a peak in September 2017-60\%. The third question also showed a trend from massive opposition to support-from the beginning of $2017,51 \%$ support and $40 \%$ opposition to $72 \%$ support and $14 \%$ opposition due to the North Korea's successful test of ICBM and Trump's aggressive attitude towards North Korea in progress. In sum, South Koreans approve THAAD and its protection effects, and south Koreans are positive about a more stable and relatively more united Korean Peninsula. These positive attitudes have been clearly shown in recent joint effort in 2018 winter Olympic. Two Koreans teams would walk in the stadium together and compete as one team in one of the sports events after recent negotiation. All these would not be possible if THAAD were not deployed and North Korea was not able to act proactively to gain control over itself geopolitically and economically. 


\section{Conclusions and Suggestions}

In 2017, DPRK has officially become a fully developed nuclear power, with ample uranium in stock, augmenting its nuclear power while threatening the U.S. with a preemptive nuclear strike on Guam islands and North Pacific Ocean, destroying marina life and potentially causing the most significant tsunami in known history. In the short term, negotiation would not be an option anymore, including economics sanction. Military actions would also cause a disaster for the world. After years of political maneuvering, the US managed to strengthen its "Rebalance to Asia Policy" by deploying THAAD to contain the nuclear threat from both China and North Korea, even Russia. Despite US's effort to depict North Korea as a "rogue state," North Korea did manage to maintain its regime and finally to be truly independent of every world powers. To that sense, THAAD did succeed on containing North Korea's nuclear capability to attack the US, but it failed to contain Kim dictatorial regime and instead provided a peaceful era for Kim Jun Un to further augmentation of power and influence in the Korean Peninsula. I thus propose that the US should plan for the long-term and seek peace in Korean Peninsula to build a positive new balance of power in the region for the benefit of North Korea people, recognizing North Korea as a normal state, not as terrorist supporter and rouge state. So, it could be a beneficial equilibrium for North Korea, South Korea, Japan, China, the U.S., and Russia in the long term. Reducing the ongoing tense between prior nations would boost the local economy and the well-being of North Korean for the less military budget is required for North Koreans to maintain a stable stance in the region and therefore able to put more resources onto economic development. Same applies to the US. Namely, US should also reduce the military budget and transfer the attention and resources onto Americans in need. Peace would benefit every Korean, furthering the communication of people, economically and culturally. Then both North and South Koreans could genuinely benefit from growing economy and peaceful life. Ultimately, in the waves of win-winism, North Korea could potentially decrease its antagonistic view on the U.S. On the other hand, if the antagonism continues, in the long run, none of the prior benefits would be effectuated, people would continue in tense and fear of a disastrous war that may be detrimental to human as a whole.

\section{References}

[1] Chanlett-Avery, Emma, et al. North Korea: U.S. Relations, Nuclear Diplomacy, and Internal Situation. Congressional Research Service, 15 Jan. 2016, www.fas.org/sgp/crs/nuke/R41259.pdf.

[2] Cohen, Saul Bernard. Geopolitics: The Geography of International Relations. Rowman \& Littlefield, 2015.

[3] Ilbo, JoongAng. Public Executions Seen in 7 North Korea Cities. Korea JoongAng Daily, 11 Nov. 2013, www.koreajoongangdaily.joins.com/news/article/article.aspx?aid=2980240.

[4] Fu, Ying. The Korean Nuclear Issue: Past, Present, and Future: A Chinese Perspective. John L. Thornton China Center at Brookings, May 2017, www.brookings.edu/wp-content/uploads/2017/04/north-korean-nuclear-issue-fu-ying.pdf.

[5] Lee, Rensselaer W., and William Severe. Time for Decisions on North Korea. Foreign Policy Research Institute, 5 July 2017, www.fpri.org/article/2017/07/time-decisions-north-korea/.

[6] Liu, Feng. Strategy and Security in the Changing World. Current Affairs Press, 2015.

[7] Liu, Cong De. Introduction to Geopolitics. China Renmin University Press, 2010.

[8] Oh, Kongdan. Understanding North Korea. Foreign Policy Research Institute, 21 Mar. 2013, www.fpri.org/article/2013/03/understanding-north-korea/. 